\title{
Analisis Biaya Mutu dalam Pengendalian Produk Cacat
}

\author{
Nur Fitratul Jamil ${ }^{*}$, Yulinartati ${ }^{2}$, Astrid Maharani ${ }^{3}$ \\ 1,2,3 Program Studi Akuntans, Fakultas Ekonomi, Universitas Muhammadiyah Jember, Jawa Timur, Indonesia
}

\section{A R T I C L E I N F O}

Article history:

Received 19 August 2019 Received in revised form 16 September 2019 Accepted 15 October 2019

Available online 30

November 2019

\section{Kata Kunci:}

Biaya Kualitas, Produk

Cacat

Keywords:

Quality Costs, Defective

Products

\begin{abstract}
A B S T R A K
Penelitian ini bertujuan untuk mengetahui bagaimana penerapan biaya kualitas di Pabrik Gula Panji Situbondo dan untuk mengetahui peran laporan biaya kualitas dalam mengendalikan produk yang cacat di pabrik gula Panji Situbondo. Metode analisis data yang digunakan dalam penelitian ini adalah analisis deskriptif kualitatif. Analisis deskriptif digunakan untuk menggambarkan variabel-variabel dalam penelitian sedangkan analisis kualitatif dilakukan untuk menghasilkan temuan berupa deskripsi subjek dan objek penelitian berdasarkan fakta-fakta di data lapangan yang diperoleh dalam penelitian, sehingga penyelesaian masalah adalah diselidiki sebelumnya dengan menggambarkan subjek atau objek penelitian. Berdasarkan hasil penelitian di Pabrik Gula Panji Situbondo, pada dasarnya perusahaan telah menerapkan biaya yang berkaitan dengan kualitas produk, tetapi perusahaan belum secara khusus mengidentifikasi dan mengategorikannya. Dengan demikian perusahaan juga tidak melaporkan hasil kualitas dan kontrol produk yang cacat secara terpisah. Oleh karena itu, menentukan biaya kualitas sebagai langkah pertama dalam melaporkan biaya kualitas sangat diperlukan bagi perusahaan jika mereka ingin meningkatkan kualitas produk mereka sambil mengurangi biaya kualitas dengan catatan penjualan yang akan meningkat.
\end{abstract}

\section{A B S T R A C T}

This study aims to find out how the application of quality costs at the Panji Situbondo Sugar Factory and to determine the role of quality cost reports in controlling defective products at the Panji Situbondo sugar factory. The data analysis method used in this study is qualitative descriptive analysis. Descriptive analysis is used to describe the variables in the study while qualitative analysis is done to produce findings in the form of descriptions of the subject and object of research based on the facts in the field data obtained in the study, so that the problem solving is investigated previously by describing the subject or object of research. Based on the results of research at the Panji Situbondo Sugar Factory, basically the company has implemented costs related to product quality, but the company has not specifically identified and categorized it. Thus the company also does not report the results of quality and control of defective products separately. Therefore, determining quality costs as the first step in reporting quality costs is very necessary for companies if they want to improve the quality of their products while reducing quality costs with a record of sales that will increase.

\footnotetext{
* Corresponding author.

E-mail addresses: nurfitratuljamil@gmail.com (Nur Fitratul Jamil)
} 


\section{Pendahuluan}

Persaingan produk pada saat ini semakin ketat, sehingga perlu adanya kualitas produk yang baik guna memenuhi kepuasan konsumen untuk tetep bertahan dalam bersaing. Semua konsumen tentu akan merasa puas jika produk yang dikeluarkan oleh suatu perusahaan adalah produk dengan kualitas yang baik dan unggul. Dengan demikian, salah satu kunci untuk unggul dalam persaingan terletak pada kemampuan perusahaan untuk menciptakan keunggulan bersaing dengan cara memberikan nilai lebih kepada pelanggan dari pesaingnya.

Salah satu strategi perusahaan untuk tetap unggul dalam bersaing sehingga mencapai kepuasan pelanggan bermula dengan pembuatan produk yang berkualitas, bermulai dari perancangan hingga pengemasan produk dan penetapan harga produk. Setelah itu barulah berlanjut pada hasil akhir untuk meyakinkan para konsumen dengan produk yang memberikan kualitas dan manfaat yang telah memenuhi kebutuhan dan keinginan konsumen sehingga mencapai kepuasan konsumen.

Kepuasan konsumen sangat berhubungan erat dengan kualitas produk maupun jasa yang dihasilkan oleh suatu perusahaan. Kualitas produk yang tinggi tentu juga akan menghasilkan kepuasan konsumen yang lebih tinggi pula. Menurut Kotler (2002), membangun masa depan bisnis yang yang berkelanjutan perlu dilakukan perbaikan-perbaikan kualitas produk yang secara terus menerus. Perbaikan kualitas ini kemudian dapat digunakan sebagai alat perancangan, pengendalian dan pengambilan keputusan terhadap kualitas produk yang dihasilkan.

Menurut Ransun (2016) Biaya merupakan pengorbanan yang di lakukan untuk mencapai suatu tujuan dan menjadi manfaat di masa yang akan datang. Khususnya di dalam suatu organisasi atau perusahaan, biaya biasa digunakan sebagai penentuan harga barang, pengendalian internal, dan sebagai informasi untuk pihak eksternal. Menurut Rahayu (2017) Biaya kualitas dapat dikelompokkan menjadi empat golongan, yaitu biaya pencegahan, biaya penilaian, biaya kegagalan internal, dan biaya kegagalan eksternal. Golongan biaya kualitas yang dikeluarkan untuk mencegah produk dari kerusakan adalah biaya pencegahan dan biaya penilaian, sedangkan biaya kegagalan internal dan biaya kegagalan eksternal tidak dikeluarkan untuk mencegah produk dari kerusakan karena biaya kegagalan dikeluarkan setelah produk itu jadi dan untuk memperbaharui produk rusak menjadi produk yang sesuai spesifikasi perusahaan. Membahas tentang biaya kualitas, salah satu perusahaan yang menerapkan biaya kualitas adalah Pabrik Gula Pandji yang berada di bawah naungan PT. Perkebunan Nusantara XI (Persero) merupakan salah satu perusahaan BUMN (Badan Usaha Milik Negara) yang bergerak dibidang agroindustri dengan mengolah tanaman tebu sebagai bahan utama untuk menghasilkan gula dan tetes. Bahan baku tebu merupakan tanaman semusim yang hanya dapat di produksi dalam satu tahun sekali. Produk Pabrik Gula Pandji telah dipasarkan nasional, sehingga mengalami persaingan yang semakin ketat dengan semakin banyak gula impor yang masuk.

Setiap proses produksi dalam suatu industri tidak dapat dihindari adanya produk cacat ataupun produk yang belum memenuhi mutu sehingga memaksa perusahaan untuk mengeluarkan biaya tambahan dalam usahanya untuk menghindari produk cacat dan meningkatkan kualitas yang dihasilkan. Demikian juga terjadi pada Pabrik Gula Panji PT. Perkebunan Nusantara XI (Persero) yang masih mengharuskan beberapa produknya melakukan proses ulang (reproses). Terdapat persediaan produk di gudang PG Panji sisa produksi tahun 2016-2017 yang masih belum memenuhi standar mutu SNI 3140.3:2010. Standar ini merupakan revisi dari SNI 01-3140-2001. Tujuan adanya standarisasi ini dilakukan untuk meningkatkan perlindungan dan acuan bagi pelaku usaha, konsumen dan masyarakat secara luas untuk menghasilkan produk yang bermutu dan aman dikonsumsi.

Terdapat beberapa sisa persediaan produk gula digudang PG Panji Situbondo pada tahun 20162017 yang masih diharuskan untuk melakukan proses ulang (reproses). Reproses ini dilakukan selama 2 tahun berturut-turut sejak tahun 2016-2017 dengan rincian sebagai berikut :

Tabel. 1. Reporses Sisa Persediaan Produk Gula (2016-2017):

\begin{tabular}{cc}
\hline Tahun & Jumlah Produk \\
\hline 2016 & $987.62 \mathrm{Kui}$ \\
2017 & $800.00 \mathrm{Kui}$ \\
\hline
\end{tabular}

Sumber : Data diolah, 2019 (Laporan Keuangan Pabrik Gula Panji Situbondo)

Wahyuningtias (2013) produk cacat yang belum memenuhi standar mutu jika harus di proses ulang tentu akan berdampak pada peningkatan harga pokok produksi disetiap prosesnya dan hal ini berdampak buruk pada tingkat persaingan. Untuk mencegah hal yang demikian terulang kembali maka perusahaan harus dapat menekan jumlah produk cacat seminimal mungkin. Cara terbaik yang dapat digunakan 
perusahaan untuk mengendalikan jumlah produk yang tidak memenuhi mutu adalah dengan mengeluarkan biaya kualitas.

Berdasarkan uraian di atas, maka perlu dilakukan penelitian tentang "Analisis Biaya Mutu Dalam Pengendalian Produk Cacat (Studi Kasus Pada Pabrik Gula Panji Situbondo".

\section{Metode}

Metode analisis data yang digunakan dalam penelitian ini adalah analisis deskriptif kualitatif. Analisis deskriptif digunakan untuk menggambarkan variabel dalam penelitian sedangkan analisis kualitatif dilakukan untuk menghasilkan temuan-temuan berupa gambaran subjek dan objek penelitian berdasarkan fakta yang ada pada data-data lapangan yang diperoleh dalam penelitian, sehingga menghasilkan pemecahan masalah yang sebelumnya diselidiki dengan menggambarkan keadaan subjek atau objek penelitian.

Sumber data yang digunakan dalam penelitian ini adalah data primer dan data sekunder yang diperoleh langsung dari perusahaan berupa laporan biaya mutu dan data jumlah produk cacat yang ada pada PG. Panji Situbondo selama tahun 2015 dan 2016.

Teknik pengumpulan data merupakan cara yang digunakan oleh peneliti untuk mengumpulkan data peneltian. Teknik pengumpulan data yang digunakan dalam penelitian ini adalah :

1. Observasi yaitu teknik pengumpulan data dengan melakukan pengamatan secara cermat terhadap objek penelitian, berupa gejala-gejala dan peristiwa yang timbul dalam proses mekanisme yang berlangsung.

2. Studi lapangan yang dilakukan untuk memperoleh data primer dengan melakukan wawancara dan observasi.

3. Penelitian dokumentasi. Penelitian dokumentasi merupakan pengumpulan data yang dilakukan dalam mengamati dokumen-dokumen yang dimiliki dan disediakan oleh perusahaan untuk kemudian diolah oleh peneliti yang berkaitan dengan biaya kualitas atau mutu dan produk cacat.

4. Penelitian kepustakaan yang dilakukan guna memperoleh data sekunder mengenai biaya pengendalian kualitas produk dan produk cacat dengan mengkaji beberapa literatur yang berkaitan dengan penelitian. Kegunaan penelitian kepustakaan adalah untuk memperoleh dasar-dasar teori yang dapat digunakan sebagai landasan teori dalam menganalisis masalah penelitian dan sebagai pedoman bekal penelitian lapangan.

Menurut Sugiono (2010), analisis data merupakan proses mencari dan menyusun data yang diperoleh dari hasil wawancara, catatan lapangan, ataupun bahan-bahan lainnya yang secara sistematis mudah dipahami dan temuannya dapat diinformasikan kepada orang lain. Teknik analisis dalam penelitian ini yaitu menggunakan teknik analisis deskriptif kualitatif.

Adapun langkah-langkah dalam penelitian ini adalah sebagai berikut: 1) Mengidentifikasi biayabiaya yang terjadi diperusahaan dalam biaya kualitas atau mutu, 2) Mengklasifikasikan (mengelompokkan) biaya kualitas atau mutu, 3) Menyusun laporan biaya kualitas atau mutu dalam bentuk data yang dapat dibandingkan dalam berbagai periode (comparative data of multiple periods), 4) Melakukan analisis tren biaya kualitas atau biaya mutu Multi periode Total Biaya Kualitas dan Biaya Kualitas Individual, dan 5) Menganalisa dampak yang dapat timbul pada laporan biaya kualitas dalam proses pengendalian produk cacat.

\section{Hasil dan Pembahasan}

\section{A. Analisis Biaya Mutu}

Berdasarkan wawancara dan data yang diperoleh pada perusahaan, Pabrik Gula Panji Situbondo belum menerapkan biaya mutu secara terpisah (khusus). Walau demikian perusahaan sudah menaruh perhatian terhadap biaya-biaya yang berhubungan dengan mutu akan tetapi pencatatan masih termasuk dalam pelaporan biaya produksi atau biaya penjualan. Dengan demikian tentunya untuk pencatatan dan pelaporan biaya mutu dan pengendalian produk cacat juga masih tidak dilakukan secara terpisah.

\section{B. Pelaporan Biaya Mutu}

Setelah seluruh biaya mutu pada Pabrik Gula Panji Situbondo diidentifikasi, selanjutnya dilakukan pengukuran pada tiap penggolongan biaya kualitas dan kemudian disusun kembali dalam laporan biaya mutu secara terpisah agar mempermudah analisis. Langkah awal dalam usaha ini adalah dengan mengidentifikasi dan mengukur besarnya biaya mutu. Sedangkan tujuan dilakukannya pengukuran biaya mutu ini adalah untuk mengidentifikasi seberapa banyak pengeluaran perusahaan untuk memperoleh produk yang bermutu. Pengukuran unsur-unsur biaya dapat digolongkan dalam biaya 
mutu teridentifikasi, yang selanjutnya dilakukan pengukuran dalam masing-masing komponen biaya mutu.

Tabel 2. Laporan Tren Multiperiode Total Biaya Mutu Pabrik Gula Panji Situbondo.

\begin{tabular}{cccc}
\hline $\begin{array}{c}\text { Periode } \\
\text { Tahun }\end{array}$ & $\begin{array}{c}\text { Biaya Mutu } \\
\text { (Rp) }\end{array}$ & Penjualan Produk (Rp) & $\begin{array}{c}\text { Persentase dari } \\
\text { Penjualan (\%) }\end{array}$ \\
\hline $\mathbf{2 0 1 6}$ & xx.xx.xxx.xxx & xx.xxx.xxx.xxx & $24,68 \%$ \\
$\mathbf{2 0 1 7}$ & xx.xxx.xxx.xxx & xx.xxx.xxx.xxx & $36,06 \%$ \\
$\mathbf{2 0 1 8}$ & xx.xxx.xxx.xxx & xx.xxx.xxx.xxx & $25,11 \%$ \\
\hline
\end{tabular}

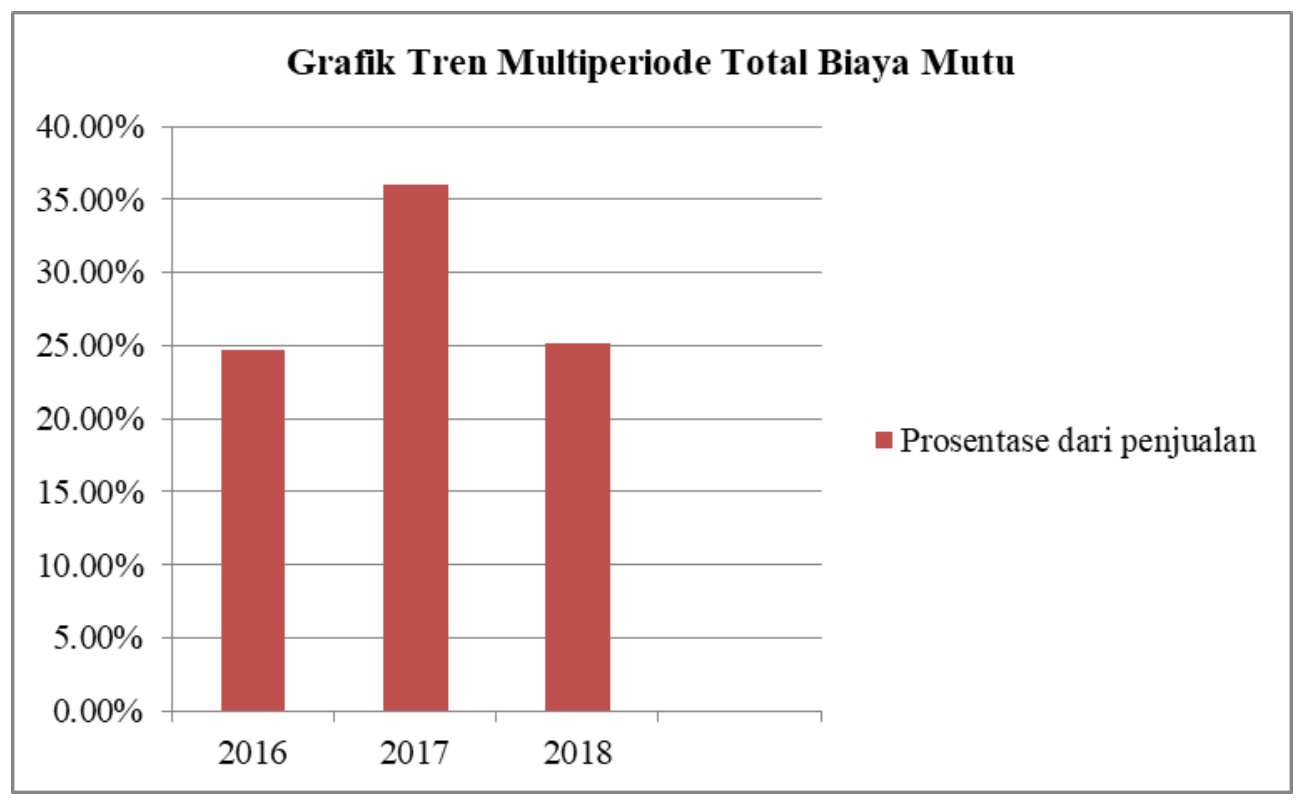

Gambar 1. Grafik Tren Multiperiode Total Biaya Mutu Pabrik Gula Panji Situbondo

Berdasarkan tabel diatas dapat diketahui bahwa biaya mutu mengalami fluktuasi. Prosentase biaya mutu yang cukup tinggi terjadi pada tahun 2017 yaitu sebesar 36,06\% dikarenakan biaya pemeliharaan mesin dan biaya $Q C$ cukup tinggi. Sedangkan Prosentase biaya mutu yang rendah terjadi pada tahun 2016 yaitu sebesar $24,68 \%$.

Guna mempermudah analisis dapat menggunakan tren untuk masing-masing kategori biaya mutu yang dinyatakan dalam prosentase dari penjualan.

Laporan biaya mutu tren satu periode digunakan guna menunjukkan kemampuan yang berhubungan dengan kinerja kualitas dalam tahun terakhir. Sehingga manajemen dengan mudah memperoleh informasi dan wawasan tambahan dengan melihat perbandingan kinerja kualitas tahun ini dengan cara membandingkan biaya mutu yang sesungguhnya dalam tahun sebelumnya. Wahana untuk bahan perbandingan tersebut adalah dengan laporan biaya mutu tren satu periode yaitu yang digunakan satu tahun.

Keunggulan dari laporan biaya mutu tren satu periode yaitu akan memungkinkan manajer untuk melihat tren jangka pendek dari program perbaikan mutu perusahaan dan dapat menghasilkan informasi yang lebih rinci terkait wilayah-wilayah yang lebih menghasilkan keuntungan. Adapun kelemahan dari laporan biaya mutu tren satu periode yaitu dalam laporan ini hanya menilai tren jangka pendek (selama 1 tahun) sehingga penurunan biaya mutu pada periode tersebut kemungkinan belum tentu dapat di pertahankan pada periode selanjutnya. Dibawah ini merupakan Tabel prosentase kategori-kategori biaya mutu terhadap penjualan. 
Tabel 3. Laporan Tren Multiperiode Kategori Biaya Mutu Individual Pabrik Gula Panji Situbondo

\begin{tabular}{ccccc}
\hline $\begin{array}{c}\text { Periode } \\
\text { Tahun }\end{array}$ & $\begin{array}{c}\text { Biaya } \\
\text { Pencegahan }\end{array}$ & Biaya Penilaian & $\begin{array}{c}\text { Biaya Kegagalan } \\
\text { Internal }\end{array}$ & $\begin{array}{c}\text { Biaya Kegagalan } \\
\text { Eksternal }\end{array}$ \\
\hline 2016 & $17,26 \%$ & $0,00 \%$ & $7,42 \%$ & $0 \%$ \\
2017 & $24,59 \%$ & $2,02 \%$ & $9,45 \%$ & $0 \%$ \\
2018 & $16,21 \%$ & $1,44 \%$ & $7,46 \%$ & $0 \%$ \\
\hline
\end{tabular}

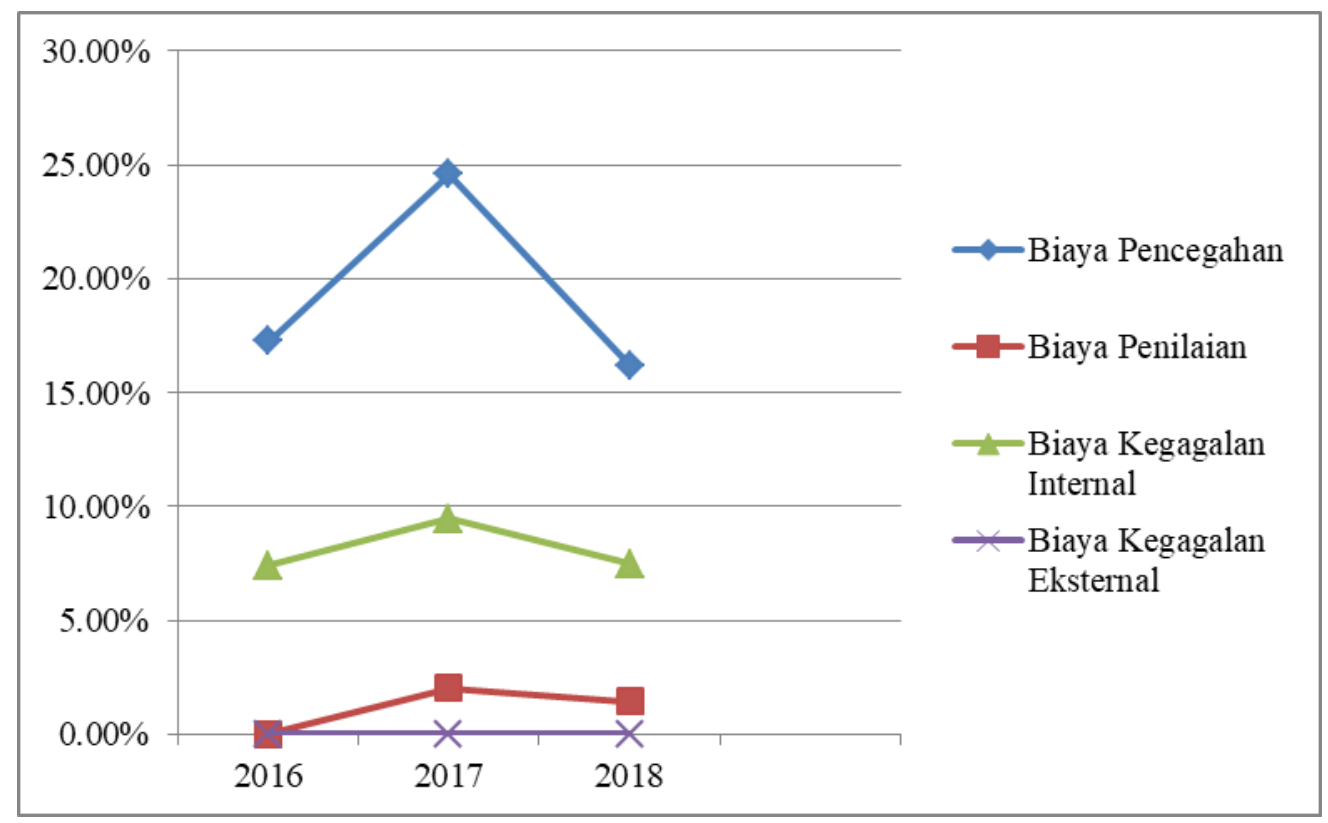

Gambar 2. Grafik Tren Multiperiode Kategori Biaya Mutu Individual

Berdasarkan diagram diatas menunjukkan bahwa Pabrik Gula Panji Situbondo telah berusaha melakukan semua upaya untuk menjaga dan meningkatkan kualitas produk, hal ini terbukti dan dapat dilihat dari data diatas bahwa pada tahun 2018 prosentase biaya mutunya lebih rendah secara keseluruhan mulai dari biaya pencegahan 16,21\%, biaya penilaian 1,44\%, dan biaya kegagalan internalnya 7,46\% jika dibandingkan pada tahun 2017 yang sangat tinggi yaitu biaya pencegahan 24,59\%, biaya penilaian 2,02\% dan biaya kegagalan internal 9,45\%.

Penekanan biaya mutu yang terjadi secara keseluruhan memang tidak stabil karena upaya untuk meminimalkan terjadinya produk cacat atau produk yang kurang memenuhi standar mutu. Peningkatan dan penurunan biaya mutu terjadi karena perusahaan melakukan upaya meminimalkan adanya produk cacat yaitu dengan mengeluarkan biaya penilaian yaitu biaya QC, pada tahun 2016 tidak ada $1 \%$ pun biaya yang dikeluarkan sedangkan pada tahun 2017 perusahaan mulai memberikan perhatian terhadap kualitas produk yaitu dengan melakukan penilaian pada produk sebelum proses produksi dan setelahnya sehingga persentase dari biaya penilaian menjadi 2,02\%. Penekanan biaya mutu ini dilakukan dengan harapan untuk mengurangi produk cacat

Jika dilihat dari hasil data yang diperoleh tersebut dapat dikatakan bahwa hampir sebagian besar biaya yang dikeluarkan oleh Pabrik Gula Panji Situbondo yaitu pada biaya pencegahan. Dalam biaya pencegahan terdiri dari biaya pabrik dan terdapat biaya pembibitan. Pada tabel 4.6 menunjukkan bahwa biaya yang paling banyak dikeluarkan oleh Pabrik Gula Panji Situbondo adalah biaya pabrik.

\section{Peranan Laporan Biaya Mutu dalam Pengendalian Produk Cacat}

Biaya mutu pada Pabrik Gula Panji Situbondo belum terencana dan dikendalikan secara tersendiri (khusus). Pengendalian produk cacat yang dilakukan oleh pabrik gula Panji Situbondo yaitu dengan cara pengerjaan kembali (rework). Pengerjaan kembali (rework) pada pabrik gula Panji Situbondo sering disebut sebagai proses ulang (reproses) yaitu proses untuk membetulkan barang cacat. Produk cacat yang terjadi karena disebabkan oleh kegagalan internal dapat berupa karena kecerobohan karyawan, atau usangnya mesin. Sedangkan produk cacat yang dimaksud dalam penelitian terjadi karena produk yang terdapat pada gudang persediaan belum memenuhi standar mutu SNI 3140.3:2010 atau dapat juga 
dikatakan sebagai produk yang mengalami penyusutan. Dengan demikian, perusahaan diharuskan melakukan reproses dan pengujian ulang.

Setelah dilakukan pengklasifikasian biaya yang tergolong biaya mutu, diperoleh informasi bahwa biaya mutu total besarannya berubah terhadap persentase penjualan. Besarnya nilai dari perubahan persentase biaya mutu tersebut cenderung meningkat, sedangkan persentase penjualan semakin menurun. Dengan demikian, meningkatnya persentase biaya kualitas total terhadap penjualan menunjukkan bahwa Pabrik Gula Panji Situbondo hampir berhasil dan sudah menarik perhatian terhadap pencegahan dari kemungkinan adanya produk cacat dan artinya kualitas produk yang dihasilkan akan semakin baik. Sehingga dengan demikian output dari produksi yang dilakukan sudah memiliki kualitas produk seperti yang diinginkan oleh pelanggan.

Pabrik Gula Panji Situbondo dapat dikatakan berhasil karena selama ini belum ada konsumen atau pelanggan yang melakukan komplain atau pengembalian barang karena rusak atau cacat, bahwasanya tidak ada pengeluaran biaya mutu pada biaya kegagalan internal. Hal ini disebabkan karena memang pabrik gula Panji Situbondo sangat berhati-hati melakukan pengecekan sebelum barang dikirim kepada semua pelanggannya.

Penurunan biaya kualitas sekaligus berkurangnya produk cacat sangat-sangat diharapkan oleh perusahaan , sehingga akan menghasilkan kualitas yang lebih unggul, atau setidaknya hampir kerusakan nol dan kualitas sempurna yang dicapai. Untuk menghasilkan produk yang sesuai dengan ekspektasi perusahaan maka perusahaan harus tetap menaruh perhatian dan menanggung biaya mutu tersebut terutama pada biaya pencegahan dan biaya penilaian.

Berikut tabel produk yang mengharuskan dilakukannya rework sebagai berikut:

Tabel 4. Gula Reproses Pabrik Gula Panji Situbondo

\begin{tabular}{cc}
\hline Tahun & Jumlah Produk \\
\hline 2016 & $987.62 \mathrm{Kui}$ \\
2017 & $800.00 \mathrm{Kui}$ \\
\hline & Sumber : Data diolah, 2019 (Laporan Keuangan PG. Panji Situbondo)
\end{tabular}

Jika dilihat dari jumlah produk cacat atau produk yang masih harus di proses ulang (reproses) pada tabel diatas maka, dapat dinyatakan bahwa Pabrik Gula Panji Situbondo telah berhasil dan mampu mengurangi produk cacat atau produk yang kurang dari mutu dengan melakukan penekanan pada biaya mutu yang sedikit lebih tinggi dari tahun sebelumnya walaupun tingkat penjualan mengalami penurunan.

Dari hasil laporan biaya mutu peningkatan keseluruhan biaya mutu mulai dari biaya pencegahan, biaya penilaian, dan biaya kegagalan internal telah membuktikan bahwa Pabrik Gula Panji Situbondo sudah menaruh perhatian terhadap kualitas produk maupun produk cacat dengan menekan biaya mutu dengan catatan mutu atau kualitas yang dihasilkan juga baik dan produk cacat semakin menurun. Hal ini dapat membuktikan bahwa Pabrik Gula Panji Situbondo sudah menunjukkan keseriusan terhadap biaya mutu dengan cara memperbaiki mutunya yang tentunya juga dengan penekanan biaya yang semakin lama akan semakin sedikit.

Penentuan biaya mutu pada analisis menunjukkan bahwa Pabrik Gula Panji Situbondo sebenarnya sudah mengeluarkan biaya yang berhubungan dengan pengendalian mutu produk dan pengendalian produk cacat yang terjadi, hanya saja dalam pelaporannya belum dilakukan secara khusus. Elemenelemen pencatatan biaya mutu masih tergabung dalam laporan biaya penjualan/laporan biaya produksi.

Biaya mutu yang tidak diidentifikasi secara terpisah ini mengakibatkan pihak perusahaan tidak memperoleh informasi yang memadai untuk melakukan evaluasi dan perbaikan dalam upaya Total Quality Managemen. Oleh sebab itu, penentuan biaya mutu sebagai langkah awal dari pelaporan biaya mutu sangat diperlukan bagi perusahaan jika ingin meningkatkan mutu produknya sekaligus menekan biaya mutu yang lebih rendah dengan catatan penjualan juga akan semakin meningkat.

\section{Simpulan dan Saran}

Berdasarkan data dan analisis yang dilakukan pada bab-bab sebelumnya, maka penulis akan memberikan kesimpulan yaitu sebagai berikut: 1) Pada dasarnya biaya yang berhubungan dengan mutu produk sudah dikeluarkan oleh Pabrik Gula Panji Situbondo. Akan tetapi pihak perusahaan belum mengidentifikasi dan mengelompokkannya, dengan demikian pelaporan biaya mutu tentunya juga tidak dilakukan secara terpisah. Adapun biaya-biaya mutu yang dikeluarkan oleh perusahaan dikelompokkan menjadi 4 golongan. Biaya pencegahan meliputi : biaya pabrik dan biaya pembibitan. Biaya penilaian meliputi : biaya $Q C$. Biaya kegagalan internal meliputi : Biaya Penyusutan. Sedangkan untuk biaya 
kegagalan eksternal belum ada pencatatan karena sampai pada saat ini masih belum ada klaim atau masih belum ada keluhan dari konsumen mengenai kualitas atau berupa pengembalian produk. 2) Dalam laporan biaya mutu dan analisis tren dapat dikatakan bahwa mutu total berubah dalam setiap periode. Hal ini menunjukkan bahwa Pabrik Gula Panji Situbondo sudah menaruh perhatian terhadap mutu produk yang dihasilkan. Dari penelitian biaya mutu dapat dianalisis bahwa Pabrik Gula Panji Situbondo sudah mengeluarkan biaya-biaya yang berhubungan dengan pengendalian mutu produk dan pengendalian produk cacat yang dihasilkan walaupun pelaporannya belum dilakukan secara khusus. Elemen-elemen biaya mutu masih tergabung dalam laporan biaya produksi. Biaya mutu yang tidak diidentifikasi secara terpisah ini mengakibatkan pihak perusahaan tidak memperoleh informasi yang memadai untuk melakukan evaluasi dan perbaikan dalam upaya Total Quality Managemen. Oleh sebab itu, penentuan biaya mutu sebagai langkah awal dari pelaporan biaya mutu sangat diperlukan bagi perusahaan jika ingin meningkatkan mutu produknya sekaligus menekan biaya mutu dengan catatan penjualan yang akan semakin meningkat.

Dari kesimpulan diatas maka penulis memberikan beberapa saran yang dapat diambil sebagai pertimbangan dan jalan keluar dalam mengatasi permasalahan yang dihadapi oleh Pabrik Gula Panji Situbondo. 1) Pabrik Gula Panji Situbondo sebaiknya memperhatikan biaya-biaya yang merupakan mutu dan mengelompokkan biaya-biaya tersebut menurut klasifikasinya. Setelah biaya mutu dikelompokkan, perusahaan akan mudah melakukan pengukuran terhadap biaya mutu tersebut, kemudian biaya-biaya tersebut dapat dilaporkan dalam satuan laporan biaya mutu. 2) Sebaiknya Pabrik Gula Panji Situbondo juga menggunakan laporan biaya mutu karena informasi mengenai biaya mutu sangat diperlukan oleh manajemen untuk mengendalikan mutu produk yang dihasilkan. Tidak hanya itu saja, informasi biaya mutu juga mempermudah manajemen dalam menghindari pemborosan dalam proses produksi. 3) Pabrik Gula Panji Situbondo sebaiknya juga menerapkan laporan biaya mutu agar dapat merencanakan dan mengendalikan mutu produk dan mengendalikan produk cacat sehingga perusahaan dapat mengambil keputusan dengan mudah dan tepat.

\section{Daftar Rujukan}

Blocher, Edward J, Kung H Chen and Thomas W. Lin. (2000). Manajemen Biaya. Edisi 1. Jakarta: Salemba Empat.

Carter, William K. (2009). Akuntansi Biaya. Edisi 14. Jakarta: Salemba Empat.

Cip tani, M. K. (2004). Pengukuran Biaya Kualitas: Suatu Paradigma Alternatif. Jurnal Akuntansi dan Keuangan.

Darmawan, I. P. A., Zukhri, A., \& Suwena, K. R. (2015). Analisis Biaya Kualitas Pada PT. Industri Sandang Nusantara Patal Tohpati. Jurnal Pendidikan Ekonomi Undiksha, 5(1).

Dewi, M.P., Handriyono., \& Wahyono, H. (2016). Analisis Pengaruh Biaya Kualitas Terhadap Tingkat Kerusakan Produk Rokok Sigaret Kretek Mesin (SKM) Pada PR. Gagak Hitam Maesan Bondowoso.

Dewi, Sofia Prima \& Septian Bayu Kristanto. (2017). Akuntansi Biaya. Edisi Kedua. Penerbit: In Media. Bogor. 1(1), 68-83.

Fardana, A. R., Susbiyani, A., \& Suwarno, S. (2017). Peranan Laporan Biaya Kualitas Dalam Perencanaan Dan Pengendalian Kualitas Produk (Studi Kasus Pada Perusahaan Rokok Gagak Hitam Bondowoso). Jurnal Penelitian IPTEKS, 2.(1).

Hansen, Don R., \& Maryanne M. Mowen, (1999). Akuntansi Manajemen. Edisi Keempat, Jilid 1. Jakarta: Erlangga.

Hansen, Don R., \& Maryanne M. Mowen, (2000). Akuntansi Manajemen. Edisi Keempat, Jilid 2. Jakarta: Erlangga.

Hansen, Don R., \& Mowen, Maryanne M. Mowen, (2009). Akuntansi Manajemen, Terjemahan Dewi Fitriasari dan Deny Arnor Kwary, 7th ed. Jakarta: Salemba Empat. 
Herawati, S. D., \& Lestari, I. C. (2012). Tinjauan atas Perlakuan Akuntansi untuk Produk Cacat dan Produk Rusak pada PT Indo Pacific.

Indonesia, Buku Paduan Standar Nasional. Gula Kristal-Bagian 3: Putih. SNI, 2010, 3140: 2010.

Komara, A. T., Djuhara, D., \& Sonia, L. (2012). Pengaruh Biaya Kualitas Terhadap Laba Bersih Perusahaan (Studi Kasus Pada PT. Pindad (Persero). Jurnal Ekonomi, Bisnis \& Entrepreneurship, 6(2), 106-117.

Kristimiaji, Aryani Y. Anni, (2011). Akuntansi Manajemen. Edisi Kedua. Cetakan Pertama. UPP STIM YKPN. Yogyakarta.

Mulyadi. (2005). Akuntansi Biaya. Edisi kedua. UPP STIE YKPN. Yogyakarta

Mulyadi. (2012). Akuntansi Biaya. Edisi ketiga. UPP STIE YKPN. Yogyakarta.

Mursyidi. (2010). Akuntansi Biaya, Bandung: Refika Aditama

Prawirosentono, Suyadi. (2007). Filosofi Baru Tentang Manajemen Mutu Terpadu Abad 21, Kiat Membangun Bisnis Kompetitif, Jakarta : Bumi Aksara.

Rahayu, Lilis Puji. 2017. Analisis Pengaruh Biaya Kualitas terhadap Produk Rusak pada UD. Batu Licin. Simki-Economic Vol. 01 No. 09 Hal. 1-16. Tersedia Pada: http://simki.unpkediri.ac.id/mahasiswa/file_artikel/2017/82bff6fdeb549e778ad94aa5f326d36f .pdf.

Ransun, Kristina Meisella, David Paul Elia Saerang, dan Jessy D. L. Warongan. 2016. Pengaruh Biaya Kualitas dan Biaya Produksi terhadap Peningkatan Kualitas Produk pada Trinity Percetakan Manado. Jurnal Berkala Ilmiah Efisiensi Volume 16 No. 04 Hal. 79-90. Trsedia Pada: https://ejournal.unsrat.ac.id/index.php/jbie/article/view/13594.

Sugiyono. (2010). Metode Penelitian Kuantitatif, Kualitatif dan R\&D. Alfabeta. Bandung.

Susanto, S. B. (2013). Laporan Biaya Kualitas Sebagai Upaya Pengendalian Kualitas Produk dalam Rangka Meningkatkan Daya Saing Perusahaan. Berkala Ilmiah Mahasiswa Akuntansi, 1(2), 25-29.

Wahyuningtias, K. A. (2013). Pengaruh Biaya Kualitas Terhadap Produk Rusak Pada CV. Ake Abadi. Jurnal EMBA: Jurnal Riset Ekonomi, Manajemen, Bisnis dan Akuntansi, 1(3).

Widilestariningtyas, Ony \& Firdaus, Dony Waluya \& Anggadini, Sri Dewi. (2012). Akuntansi Biaya. Edisi pertama. Graha Ilmu.Yogyakarta.

Winarno, S. H. (2015). Analisis Pengaruh Biaya Kualitas Terhadap Tingkat Keuntungan Perusahaan (Studi Kasus Pada CV. Meranti Manunggal Furniture). Moneter-Jurnal Akuntansi dan Keuangan, 2(2). 